\title{
THE IMPORTANCE OF BRAND ON B2B MARKETS: EXPERT INTERVIEWS WITH HILTI AG MANAGERS
}

\author{
Konečný, M., Kolouchová, D.
}

This paper investigates the importance of brand building in the business-to-business world. Not only B2C companies must take branding into account and put it among their top priorities in order to survive and succeed on the market. The first part of the article deals with the theoretical background of brand importance and market specifics of B2B markets and results in the setting of two hypotheses. The following research has to find out how the managers of a pure business-to-business company perceive the importance of a brand; moreover, it has to evaluate the importance of eight specific brand building factors. Fourteen expert interviews document the growing of brands in the B2B market and their main aspects. At the end of the article, we will focus on future implications for B2B management.

JEL classification: M31

Keywords: Brand building; B2B market; brand importance in B2B; qualitative research; expert interviews.

\section{Introduction}

Brands, their build-up, development, and valuation are topics which companies deal with on a daily basis. Brand is one of the driving factors of the company's success. This applies to both business-to-customer (B2C) and business-to-business (B2B) markets and environments. Consumer brands and B2C markets are being discussed and studied very often and represent the majority of the focus. They concern the majority of the population and draw public interest. On the other hand, B2B brands are mostly not known publicly. They might not be important to all people; however, they influence their lives indirectly and should receive more attention too, especially from the business point of view.

Brand is not just name or logo or picture or symbol. It is much more. Miletsky and Smith (2009) define brand as the following: "A brand is the sum total of all user experiences with a particular product or service, building both reputation and future expectations of benefit." Brand identifies the product or service of one seller and differentiates it from other similar competitive products (Kotler, 2008). Brand consists of both intangible and tangible parts. The intangible parts such as emotions, experience, reputation and benefit expectations create the value. Then the logo together with all kinds of fonts, colors, formats, music, symbols, and wording represent the tangible part of the brand of a company. Both provide customer expectations about the product quality, price and image (Davis and Baldwin, 2005). Brands are assets and represent great value for the company (Emarald Insight Staff, 2004). Brand is basically a reputation, the total sum of past customer experiences with the products or services. Branding therefore is in charge of managing this experience on a constant and continuous basis with the objective to enhance and improve this experience in the most positive way possible. Its task is to set the expectations of customers on the right level so that they are met by the brand itself and create customer satisfaction (Miletsky and Smith, 2009). An excellent brand brings in money.

\section{Market Specifics in B2B Environment}

Companies operating on the $\mathrm{B} 2 \mathrm{~B}$ market have in common two highly important characteristics. Firstly, these companies have to start with identifying and fully understanding the needs of their potential customers and move from this point on. Secondly, it is convenient for them to collect, analyze and take advantage of the 
information about customers and competitors so they can reach their business goals. Overall, B2B markets possess several unique characteristics such as demand specifics, selling and buying procedures, its global scope and quite a specific exchange and relationship between companies (Fill and McKee, 2011). Both sides have to be active. In contrast, on the $\mathrm{B} 2 \mathrm{C}$ market, companies are the ones who are active in marketing and customers are more passive and waiting for the supply. Another diverse aspect of the B2B market is the complexity and length of the buying process and decision making processes and their risks.

In contrast to the $\mathrm{B} 2 \mathrm{C}$ market where the relationship between the company and customers is considered relatively weak and not that significant, B2B companies build their success on having long-term and stable relationships with their customers, i.e. other companies. Relationship building is much more personalized in B2B markets than it is in consumer markets. Feedback plays a significant role in $\mathrm{B} 2 \mathrm{~B}$ relationships. It is a very effective way of market research and incentive. Enabling customers to participate in brand building and to make them feel integrated and included in the whole process is perceived as a modern way of customer involvement and one of the factors of building a strong and sustainable brand. With engaged customers it is easier to transmit the main brand message and calculated brand promise (Fisher-Buttinger and Vallaster, 2010). Companies should actively ask their customers if they understand the brand message and its value proposition. This is extremely valid in B2B markets.

Building a brand through engagement also means focusing on employees. They need to be engaged in the first place in order to build a quality base for building a strong brand and for engaging customers. Employees are part of the company's integrity and should be well selected, trained and motivated to represent their company (Sadhna, 2009). A brand needs to engage employees who are motivated to deliver the expected brand promise and participate in its further development.

B2B brands are quite often corporate / company brands, so it is necessary to respect a company's point of view from this perspective. Building a strong B2B brand also means aligning the brand promise with key stakeholders in order to constantly enhance the processes and infrastructure that enclose the brand itself.

In the present market conditions, marketing cannot be done just by the marketing department. The sales team grows ever more important for the whole process of bringing a desirable product and brand to the customer. A sales person must notice clients in a deeper way in order to understand them not only for the purpose of sale, but for the sake of marketing information about brand and product. Then the interaction and proper communication between sales and marketing teams is crucial so that sales can provide relevant and detailed feedback about the brand and product from the target customers. Ideally, the outcome is optimization and adjustment of the brand offering and right value proposition to meet the expectations and needs of every single customer.

The B2B environment has considerable marketing limitations with regard to how to market a brand in comparison with B2C world. The goal is not to reach a large audience but the right targeted one. In addition to traditional B2B marketing communication instruments such as email, direct mail, telephone and direct sales, which have great influence on brand building, trade-show marketing also exists. It can enhance brand building as one of the factors, if designed and organized properly.

Last but not least, B2B markets are strongly dependent on information systems. The bigger and more complex the company is, the more sophisticated and individually customized are the system needs.

\section{Brand Importance in B2B Markets}

Brands drive the success and growth of the company. Thanks to the use of brands, a company can implement and take advantage of premium pricing, and invoke emotional connections with customers through which it can generate loyal customers (Miletsky and Smith, 2009). A brand supports and encourages revenues, profits, cash flows and increases market capitalization of the company if managed well. According to one study, brand accounts for up to $20 \%$ of stock performance of the company, $7 \%$ on average (Gregory and Sexton, 2007). Strong brands are a powerful tool which influence many aspects, not only a company and its success, but the market environment as well. Brands have the ability to command market share (Bhattacharya and Datta, 2010), create barriers to entry for competitors, help to launch new products, enter new markets easier, attract and retain talent, establish premium pricing, have more loyal customers, and build and preserve trust (Miller and Muir, 2005).

Brand building in the $\mathrm{B} 2 \mathrm{~B}$ environment is still regarded as an underdeveloped and underestimated area (Mudambi, 2002). But the perception of brand importance and purpose on business markets is changing and companies and brand management are starting to focus on brand as well (Fill and McKee, 2011).

The basic question is whether it is equally relevant for B2B companies to build a strong brand as it is for 
companies operating in the B2C market. There have been several studies conducted on this topic; they have various findings. One group suggests that brand is just one of the drivers of customer purchase decisions (Sadhna, 2009) or that organizations during their purchase decisions pay more attention to company and products or services offered than brand name (Kuhn and Alpert and Pope, 2008), but more papers and conclusions claim exactly the opposite - that brand is vastly important for B2B companies and it does matter a lot as it states for example in Mudambi (2002), Fill and McKee (2011) and Kotler and Pfoertsch (2006). In addition, there is one more compromising alternative, such as dividing the purchasing situation between high-risk and low-risk. According to Brown et al. (2011), in high-risk purchasing situations, brand will matter most and in contrast, in low-risk purchasing situations, attributes such as price will prevail over the importance of brand.

\section{Research Objective and Defined Hypotheses}

The research objective was to find out how the managers of a pure B2B company - Hilti AG - perceive the importance of brand in the $\mathrm{B} 2 \mathrm{~B}$ environment in comparison with the $\mathrm{B} 2 \mathrm{C}$ environment, and what role brand plays in their managerial profession across different business units and departments.

Hilti AG, a global provider of building construction tools and consumables, has been operating in the B2B market for more than 70 years. Founded in 1941, the worldwide Hilti Group evolved from a small family company. Since 2000, the Martin Hilti Family Trust holds all shares and, since January 2008, all participation certificates of Hilti Corporation. From five employees in 1941, the company has grown significantly and now employs nearly 22,000 people in more than 120 countries worldwide (Hilti, 2012). Hilti is a very unique company in that its main sales are gained through its direct sales force which is the core of the business model. The reason for this is because the original tool developed by the company was a direct fastening tool. A demonstration to the customer is extremely necessary to highlight the speed and simple use of this tool. It also encourages relationships to be developed between Hilti and its contractors. The company has kept this structure in place and today has more than 200,000 daily direct customer contacts (Hilti, Hilti Corporate Website, 2013).

Hilti AG was chosen for this research because of its representativeness. It is a company which has successfully expanded its brand into the international marketplace and based on its long-term success, it can be assumed that Hilti managers manage the Hilti brand very well.
Among other reasons, the Hilti company was selected due to data availability.

Two major topics - general importance and role of a brand and specific factors of brand importance - were chosen to create two hypotheses for the research. To verify the validity of them, the Hilti company setting and industry are used as a case study with regard to the Hilti environment and personal perception of Hilti managers in the Liechtenstein headquarters and a local market organization in the Czech Republic.

$\mathrm{H} 1$ : Brand is perceived by the interviewed managers of Hilti as equally important for companies in both $\mathrm{B} 2 \mathrm{~B}$ and $\mathrm{B} 2 \mathrm{C}$ markets.

$\mathrm{H} 2$ : The brand is perceived by the interviewed managers of Hilti as an important influencing factor for the B2B companies in eight areas segmented into three different groups:

- Group A - Soft aspects:

o Loyalty and relationship with customers (1)

o Emotions in customer purchase decisions (2)

o Talent attraction (3)

- Group B - Financial aspects:

o Price premium (4)

o Company value (5)

o Profit margin and cash flow (6)

- Group C - Market aspects:

o Foreign and market expansion (7)

o Differentiator due to marketing limitations (8)

\section{Research Methodology}

To detect the importance of brand on B2B markets, expert interviews were used. This allows a more open and confidential environment where more details and experience can be shared. Expert interviews were conducted with Hilti managers across different business units and departments of Hilti AG - people in general product marketing, brand management, sales and top management in Liechtenstein and Czech Republic were interviewed. The interviews had the format of open-ended questions based on a semi-structured questionnaire, which provided the managers a wide range of space and possible answers and also enabled the asking of follow up questions to dig more into detail. Twelve managers and two customers were interviewed; each interview took a maximum of 60 minutes. Research includes only a limited amount of expert interviews. These answers cannot be generalized and are only the views and opinions of a specific group of one company - Hilti AG. 


\section{Research Findings}

There have been numerous opinions and arguments for the equality of brand importance on both business and consumer markets and for bigger importance of brands in the B2C setting. None of the respondents actually mentioned anything about brand being more important for B2B markets. Based on this, we can consider brand being important equally in both markets, and still being more important in consumer markets. It is interesting to point out that the managers who believed that brand is still more important for $\mathrm{B} 2 \mathrm{C}$ companies were mostly from the sales department.

Equality of brand importance was mostly focused on limited differentiation of products in terms of price, quality, performance and service. Brand helps to distinguish among the product offer.

The overall majority of respondents agreed that brand is an important influencing factor in the following areas: emotions in customer purchase decisions (2), talent attraction (3), price premium (4), company value (5), profit margin and cash flow (6).

Three other areas - loyalty and relationship (1), foreign and market expansion (7), differentiator due to marketing limitations (8) - were agreed on by most recipients but with some conditions or objections.

Loyalty and relationship with customers (1) was one of the areas where the opinions varied the most. Mostly people agreed that with a strong brand, a company generates more loyal customers. Also good experience with products and services, which means delivering brand promise, generates loyal customers, not the brand itself. Some respondents pointed out that even a strong brand would not prevent them from going to the competition if the price were too high.

There was almost a full consensus that brand has an influence on emotions in the customer purchase decision (2) process in the B2B market and the Hilti world in particular. No matter whether we are in B2B or $\mathrm{B} 2 \mathrm{C}$ environment, we are dealing with decision making people even in the bigger group of managers involved in purchasing decision. What is more, customers are usually small- to medium-sized firms and the decision is often made by the owner and director himself.

The statement that brand or a strong well-known brand attracts more talent (3) and talented employees to the company was confirmed by most of the interviewed managers. The opinion was very similar across all departments, level of seniority and gender. But it could have geographical limitations based on brand image in a specific country.
The initial idea that with branded products, particularly the Hilti brand, a company can ask for a premium price (4) was confirmed by the majority of respondents. Nevertheless, Hilti managers are aware that brand is not the only driver for premium price positioning. It has to be accompanied by a high quality product and good service level.

In terms of company value (5), the Hilti brand was not confirmed as the most valuable asset the company has. Brand was mentioned as an important asset, but in comparison to people, business model and innovation processes Hilti managers do not see brand as that significant.

Although it was difficult to estimate the influence of brand on profit margins and cash flow (6) on products and services, the general understanding is that brand has some influence on it and steers cash flow in a positive way. Furthermore, it is strongly dependent on the product type, price range and regional business unit.

The foreign and market expansion (7) aspect has two dimensions. Firstly, the influence and effect of brand in entering new countries with current products was perceived as questionable by the respondents. It might help in terms of a strategic approach to enter a new country with a similar population, region, natural resources, level of development, etc. Secondly, on the other hand, brand clearly helps the company to enter a new market segment or business area. But it should be a business area which is close to the core of the company's business.

Everyone agreed to a varied extent that brand is a strong differentiator (8) from the competition and helps the company distinguish itself clearly from other companies in the business construction environment.

Besides the evaluation of hypotheses, a couple more questions about perception of brand importance in B2B markets in general were asked. The following opinions were highlighted. The brand is more significant for B2B companies nowadays then it used to be in the last century because product differentiations are becoming less significant. The B2B market is now more competitive, and more fragmented with many new players. Consistency was stressed as the most fundamental aspect for successful global brand building. Consistency in all actions of the company must be aligned. B2B companies in general have to build the same brand associations in customers' minds in all countries all over the world. Keeping the brand promise was evaluated as one of the most important elements. The constantly raising brand awareness was mentioned as a critical brand building factor. 


\section{Managerial Implications}

This paper's results have confirmed previously existing theories as well as uncovered a new context of brand importance in the B2B environment. Based on expert interviews, the following advice and recommendations for B2B market were identified:

- It does not matter if companies operate in business or consumer markets, they should pay intensively close attention to their brand. Brand is becoming more and more of a key differentiator from the competition due to what is stands for also in the B2B environment.

- Brand promise has to be defined and always be delivered to customers via positive experience with the products and services. It creates loyalty. It is better to under-promise and over-deliver, than the other way around.

- Be aware that brand has an emotional influence on customer behavior and customer purchase decisions in the B2B market. Purchasers and decision-makers are people too.

- A B2B company has to build a strong, reliable, and trustworthy brand that delivers its brand promise in order to ask for a premium price which customers are willing to pay. Premium pricing also requires a high quality product and adequate level of service.

- Use the brand more in the recruiting process, especially in the specific industry environment or geographic area where it can attract more people who already know the company and brand. Invest in people; they might be the biggest asset and make the difference. Make people proud to work for the brand.

- Use previous knowledge and experience when expanding to a new country or business area. Take advantage of market similarities in terms of size, population, applications, culture, population density, number and size of cities, market regulations, authority approach, market specifics, competition success and analysis, salary level, price level, inflation, standards of living, GDP and other economic attributes, political situation, level of democracy, legal conditions, neighboring countries, trends and future outlook.

The most fundamental prerequisite for successfully building a global B2B brand is consistency. It plays an important role in every single touch-point between the company, its employees and the customers and overall market environment.

\section{Conclusion}

This paper had a clear goal to evaluate the importance of brand building in the B2B market. From the research literature and its findings, two main hypotheses for the research were drawn and verified among respondents recruited in a pure B2B company. The first hypothesis that brand building is perceived as equally important for companies in both B2B and B2C markets was mostly approved. Respondents from brand management of the company or marketers have mostly come to the conclusion that brand is equally important on both markets. The majority of management fully agreed with the five brand influencing factors suggested in the second hypothesis: emotions in customer purchase decisions (2), talent attraction (3), price premium (4), company value (5), profit margin and cash flow (6). The most frequently mentioned aspect of the brand building was consistency. Consistency is considered as a corner stone in every brand building dimension.

\section{References}

Bhattacharya, K., Datta, B. (2010, April-June). TATA Steelium - A Success Story in B2B Branding. Vikalpa: The Journal for Decision Makers, 35 (2): 101-126.

Brown, B. P. et al. (2011). When do B2B brands influence the decision making of organizational buyers?

An examination of the relationship between purchase risk and brand sensitivity. International Journal of Research in Marketing, 28 (3): 194-204.

Davis, M., Baldwin, J. (2005). More than a Name: An Introduction to Branding. Lausanne: AVA Publishing.

Emarald Insight Staff. (2004). Building a Brand. Bradford: Emarald Group Publishing Ltd.

Fill, Ch., McKee, S. (2011). Business Marketing Face to Face: The Theory and Practice of B2B Marketing. MSA, USA: Goodfellow Publishers Limited.

Fisher-Buttinger, C., Vallaster, Ch. (2008). Connective Branding: Building Brand Equity in a Demanding World. Hoboken, NJ, USA: Wiley.

Gregory, D. E., James, R. (2007). Hidden Wealth in B2B Brands. Harvard Business Review , 85 (3): 23-23.

Hilti, C. (2013). Hilti Corporate Website, (accessed March 30, 2013), [available at: http://www.hilti.com/holcom/ page/module/home/browse_main.jsf?lang=en\&nodeId=8048\&tabId $=-8048]$.

Konečný, M. (2013). The Importance of Brand on B2B Markets: Case Study of Hilti. Diploma thesis.

Kotler, P. (2008). Principles of Marketing. New Jersey: Paerson. 
Kotler, P., Pfoertsch, W. (2006). B2B Brand Management.

Authors Heidelberg / New York: Springer.

Kuhn, K. L., Alpert, F., Pope, N. K. (2008). An application of Keller's brand equity model in a B2B context. An International Journal, 11 (1): 40-58.

Miletsky, J. I., Smith, G. (2009). Perspectives on Branding. Boston: Course Technology.

Miller, J., Muir, D. (2005). Business of Brands. Chichester: John Wiley \& Sons Ltd.

Mudambi, S. (2002). Branding Importance in Businessto-Business Markets: Three Buyer Clusters. Industrial Marketing Management, 31 (6): 525-533.

Sadhna, M. (2011). Brand Management. Jaipur: Book Enclave. CEMS International Management University of Economics, Prague \& University of Cologne martin.konecny@cemsmail.org martin.Konecny@eads.net

Ing. Daniela Kolouchová Faculty of Business Administration University of Economics, Prague nám. W. Churchilla 4, Praha 3, 13067 daniela.kolouchova@vse.cz 